\title{
Antitumoural and antiangiogenic activity of Portuguese propolis in in vitro and in vivo models
}

\author{
Ricardo Silva-Carvalho ${ }^{a, b}$, Vera Miranda-Gonçalves ${ }^{a, b}$, \\ Ana Margarida Ferreira c, Susana M. Cardoso d, Abílio J.F.N. Sobral e, \\ Cristina Almeida-Aguiar ${ }^{f}$, Fátima Baltazar ${ }^{a, b, *}$ \\ ${ }^{a}$ Life and Health Sciences Research Institute (ICVS), School of Health Sciences, University of Minho, 4710-057 \\ Braga, Portugal \\ b ICVS/3B's - Government Associate Laboratory, 4710-057 Braga/Guimarães, Portugal \\ ' Chemistry Centre Vila Real (CQVR), University of Trás-os-Montes e Alto Douro, Vila Real, Portugal \\ d CERNAS, School of Agriculture, Polytechnic Institute of Coimbra Bencanta, Coimbra 3045-601, Portugal \\ e Chemistry Department, University of Coimbra, Coimbra 3004-535, Portugal \\ ${ }^{\mathrm{f}}$ CITAB, Centre for Research and Technology of Agro-Environmental and Biological Sciences, University of \\ Minho, Braga, Portugal
}

\section{A R T I C L E I N F O}

Article history:

Received 24 April 2014

Received in revised form 3

September 2014

Accepted 10 September 2014

Available online 22 October 2014

Keywords:

Portuguese propolis

Cancer

Antitumoural activity

Antiangiogenic activity

Cancer metabolism

\begin{abstract}
A B S T R A C T
Propolis, a natural product, has important biological properties, however, studies with Portuguese propolis are scarce. Thus, we aimed to characterize the chemical composition and the antitumoural and antiangiogenic activities of a sample from Pereiro (Portugal). The chemical profile of our propolis sample (P10.EE) is similar to the poplar propolis type. P10.EE decreased cell viability of different tumour cells, being less cytotoxic against non-tumoural cells. P10.EE decreased MDA-MB-231 and DU145 cell proliferation and migration, with cell cycle changes and increased cell death. The increased glucose consumption and lactate production in MDAMB-231 cells is explained by an increased expression of different metabolism-related proteins. P10.EE induced a decrease in HBMEC cells total biomass and proliferation and decreased vessel sprouting in the chicken chorioallantoic membrane. Additionally, P10.EE potentiates paclitaxel effect in MDA-MB-231 and DU145 cells. Concluding, P10.EE can be a good candidate for cancer drug development since it affects different characteristics that dictate tumorigenesis.
\end{abstract}

() 2014 Elsevier Ltd. All rights reserved.

Abbreviations: CAM, chicken chorioallantoic membrane; CAPE, caffeic acid phenethyl ester; BrdU, 5-bromo-2'-deoxyuridine; HPLC$\mathrm{MS}^{\mathrm{n}}$, high-performance liquid chromatography-mass spectrometry; IC $\mathrm{C}_{50}$, half maximal inhibitory concentration; P10.EE, ethanolic extract (EE) of Pereiro (P) propolis collected in 2010

* Corresponding author. Life and Health Sciences Research Institute (ICVS), School of Health Sciences, University of Minho, $4710-057$ Braga, Portugal. Tel.: +351 2536048 28; fax: +351 253604820 .

E-mail address: fbaltazar@ecsaude.uminho.pt (F. Baltazar).

http://dx.doi.org/10.1016/j.jff.2014.09.009

1756-4646/@ 2014 Elsevier Ltd. All rights reserved. 


\section{Introduction}

Over the years, natural products have been a rich and a promising source for discovery of new pharmaceutical agents, since they are the source of many active compounds, such as polyphenols, terpenoids, alkaloids and other nitrogen compounds, carbohydrates and lipids (Gordaliza, 2007; Manach, Hubert, Llorach, \& Scalbert, 2009). It is estimated that $60 \%$ of the world's population has a great dependence on plants for medication (Bankova, 2007). In fact, more than half of the currently existing drugs are natural compounds or related (Newman \& Cragg, 2007) and over $70 \%$ of anticancer drugs are derived from natural compounds (Watanabe, Amarante, Conti, \& Sforcin, 2011). This is an area of research that is growing continuously and is of enormous interest. Since natural compounds present different structural varieties, they can be used to obtain lead compounds for therapeutic improvement through molecular modification (Watanabe et al., 2011). Despite the use of herbs and other natural plant products as interesting sources of investigation, modified plant products by animals have been largely ignored and wasted (Umthong, Phuwapraisirisan, Puthong, \& Chanchao, 2011). In the last few years there has been an increased interest in a modified plant product produced by bees: propolis or bee glue (Sforcin \& Bankova, 2011).

Propolis, a natural product used since almost immemorial times, is a complex natural resinous mixture collected from several plants, buds and exudates by honeybees (Apis mellifera), that is obtained by mixing beeswax and salivary enzymes with the collected resin (Bankova, 2005a, 2005b; Bankova, de Castro, \& Marcucci, 2000; Barlak et al., 2011; Fokt, Pereira, Ferreira, Cunha, \& Aguiar, 2010). Generally, propolis is composed of resin, wax, essential oils, pollen and other substances and it includes minerals and organic compounds like phenolic acids or their esters, flavonoids, terpenes, aromatic aldehydes and alcohols, fatty acids, stilbenes and $\beta$-steroids (Bankova, 2005a; Barlak et al., 2011). Nevertheless, the standardization of the chemical composition of propolis is difficult since it depends on the plant sources and on the geographical and climatic conditions of the site of collection (Bankova, 2005a, 2005b; Barlak et al., 2011; Sforcin \& Bankova, 2011). More than 300 compounds were identified using different analytical approaches (Bankova, Popova, Bogdanov, \& Sabatini, 2002; Fokt et al., 2010; Gomez-Caravaca, Gomez-Romero, Arraez-Roman, Segura-Carretero, \& Fernandez-Gutierrez, 2006; Popova et al., 2004). Propolis samples from Europe, North America and other temperate zones are mainly composed of flavonoids (pinocembrin, pinobanksin, quercetin, chrysin and galangin), phenolic acids and their esters (Bankova et al., 2000; Falcão et al., 2010) whereas propolis from tropical areas, like Brazil, is composed essentially by prenylated phenylpropanoids and caffeoyl quinic acids (Bankova et al., 2000). Portuguese propolis, although little studied, appears to be composed of phenolic acids and flavonoids, similar to the ones found in European samples. However, it also composed of several other methylated, esterified and hydroxylated derivatives of common poplar flavonoids, such as crysin-5-methyl ether and kaempferol-5methyl ether, and rare derivatives of pinocembrin and pinobanksin that contains in their structure a phenylpropanoic acid derivative fraction, like pinobanksin-5-methyl-ether-3-Opentanoate and pinobanksin-3-O-butyrate or isobutyrate. Furthermore, the presence of different flavonoid glycosides in the chemical composition of some Portuguese propolis, like quercetin-3-O-rutinoside, glucuronide, glucoside or rhamnoside, kaempferol-3-O-rutinoside, isorhamnetin-O-glucuronide, quercetin-dimethyl-ether-O-rutinoside or glucuronide and kaempferol-O-p-coumaroylrhamnoside, turn such national samples chemically uncommon and different from the temperate propolis type (Falcão et al., 2010, 2012).

Propolis possesses different biological and pharmacological actions, including antibacterial and antifungal (Bankova, Popova, \& Trusheva, 2014; Fokt et al., 2010; Ordonez, Zampini, Moreno, \& Isla, 2011; Scazzocchio, D’Auria, Alessandrini, \& Pantanella, 2006; Sforcin \& Bankova, 2011; Silva, Rodrigues, Feas, \& Estevinho, 2012), antiviral (Amoros, Simoes, Girre, Sauvager, \& Cormier, 1992; Gekker, Hu, Spivak, Lokensgard, \& Peterson, 2005; Kai et al., 2014), anti-inflammatory (Hu et al., 2005), antioxidant (Cardoso, Ribeiro, Ferreira, \& Cristina Rego, 2011; Miguel, Nunes, Dandlen, Cavaco, \& Antunes, 2010; Moreira, Dias, Pereira, \& Estevinho, 2008; Valente, Baltazar, Henrique, Estevinho, \& Carvalho, 2011) and immunomodulatory (Chan, Cheung, \& Sze, 2012; Orsolic \& Basic, 2003; Sforcin \& Bankova, 2011). In the last few years, several in vitro and in vivo studies have also shown antitumoural activity of propolis from different geographic origin and of some of its isolated compounds on various tumour and non-tumour cells (Barlak et al., 2011; Chan et al., 2012; Lofty, 2006; Umthong et al., 2011; Valente et al., 2011; Wu et al., 2011). Briefly, this natural product can block specific oncogenic signalling pathways (e.g. $\beta$-catenin, c-myc, NF- $\mathrm{kB}$ and some intermediary of the PI3K/AKT pathway), which in turn leads to a decrease in cell proliferation and growth and can also act by decreasing the cancer stem cell population, increasing apoptosis, exerting antiangiogenic effects and modulating the tumour microenvironment, more specifically suppressing the invasion and migration (Chan et al., 2012). Results obtained so far allow to confirm the various propolis biological properties as well as its safety, increasing the interest in the use of propolis as a functional food and nutraceutical that may provide a health benefit (Fokt et al., 2010).

Portuguese propolis has been highly neglected by both beekeepers and the scientific community. Hence, the biological properties of this resin have been little explored and the few studies available focused the chemical composition (Falcão et al., 2010, 2012; Miguel et al., 2010), antioxidant activity (Miguel et al., 2010; Moreira et al., 2008; Valente et al., 2011), and antitumour activity on renal cell carcinoma (Valente et al., 2011) and human colorectal cancer (Valença et al., 2013) of a limited number of samples harvested in some regions of Portugal.

Thus, this study was developed with the aim to analyze the chemical composition and the antitumoural activity, more specifically the effects on cell proliferation, cell cycle and death, migration, metabolism and angiogenesis, of a Portuguese propolis sample collected in an apiary located in the central region of the country (Pereiro, Guarda). In addition to the scientific knowledge obtained, such studies allow valuing a product often neglected even by the beekeepers, therefore helping to value and to diversify the product offer of an important sector of the Portuguese economy. 


\section{Materials and methods}

\subsection{Preparation of propolis extracts}

Propolis was collected by Pedro Fernandes (Mel do Abel) in 2010 from A. mellifera beehives, by conventional scraping, in an apiary (Pereiro, N 40 44'57.135", W 70'59.403", elevation: 672,600 m) located in the central region of Portugal (Beira Alta), in the district of Guarda, city of Pinhel. After collection, propolis sample was frozen at $-18{ }^{\circ} \mathrm{C}$. The raw propolis was ground into small pieces and subsequently extracted with absolute ethanol at room temperature according to Valença et al. (2013). After extraction, a sample with a dry weight of $26.05 \mathrm{~g}$ was obtained. Ethanolic extract of Pereiro propolis (P10.EE) was dissolved in dimethyl sulphoxide (DMSO) to a $500 \mathrm{mg} / \mathrm{mL}$ stock solution.

\subsection{Total polyphenol and flavonoid content analysis}

Determination of total phenolic content was performed according to the Folin-Ciocalteu colorimetric method (Singleton, Orthofer, \& Lamuela-Raventos, 1999). Quantification of total flavonoid content was performed according to the method described by Woisky and Salatino (1998). Quercetin was used as standard for both quantifications.

\subsection{HPLC-DAD-ESI-MSn analysis}

The HPLC-DAD-ESI-MSn analysis was performed on an Ultimate 3000, Dionex separation module equipped with PDA (Varian Prostar) detector and coupled to a mass spectrometry (MS) (Thermo Scientific, Waltham, MA, USA). The column used was a $250 \mathrm{~mm} \times 4,6 \mathrm{~mm}$ id, $5 \mu \mathrm{m}$ bread diameter, end-capped Nucleosil C18 (Macherey-Nagel). The mobile phase was composed of two solvents: (A) $0.1 \%(\mathrm{v} / \mathrm{v})$ formic acid in water, and (B) acetonitrile. The flow rate was $1 \mathrm{~mL} / \mathrm{min}$ and spectral data for all peaks were acquired in the range $200-600 \mathrm{~nm}$. The mass spectrometry (MS) used was an Amazon SL (Bruker Daltonics, Bremen, Germany) ion trap MS equipped with an electrospray ionization (ESI) source. Control and data acquisition were carried out with the Compass Data Analysis system (Bruker Daltonics). The nitrogen gas pressure (above 99\% purity) was $520 \mathrm{kPa}$ (75 psi). The instrument was operated in negative-ion mode, with ESI voltage set at $5.00 \mathrm{kV}$ and the dry temperature at $200^{\circ} \mathrm{C}$. The full scan covered the mass range from $\mathrm{m} / \mathrm{z} 70$ to 700 . CIDMS/MS and $\mathrm{MS}^{\mathrm{n}}$ experiments were performed on massselected precursor ions using standard isolation and excitation configuration. Full scan data acquisition was also performed from $\mathrm{m} / \mathrm{z} 70$ to 700 in MS scan mode. The collision energy used was between 10 and 40 (arbitrary units).

\subsection{Cell lines and cell culture}

MDA-MB-231, MDA-MB-468 and MCF7 (breast cancer) were obtained from American Type Culture Collection (ATCC) or from collections developed by Drs Elena Moisseva (University of Leicester, Leicester, UK), Marc Mareel (Ghent University Hospital, Belgium) and Eric Lam (Hammersmith Hospital, London, UK). DU145 and 22RV1 (prostate cancer) and U251 and SW1088 (glioblastoma) were obtained from ATCC. Human brain microvascular endothelial cells (HBMEC) were obtained from Dr. Kwang Sik Kim (Johns Hopkins University School of Medicine, Baltimore, MD, USA). The immortalized non-tumoural breast cell line HB4a and the prostate epithelial cell line PNT-1 were provided by Dr. Rui M. Reis (ICVS/3B's-PT Government Associate Laboratory, Braga, Portugal and Barretos Cancer Hospital, São Paulo, Brazil) and purchased from the European Collection of Cell Cultures (ECACC, Salisbury, UK), respectively. A primary culture of human dermis fibroblasts (hDFb190) was provided by Mariana Cerqueira and Alexandra Marques (ICVS/ 3B's-PT Government Associate Laboratory, Braga, Portugal). Breast and brain cancer cell lines and HB4a cells were maintained in Dulbecco's Modified Eagle's Medium (DMEM 1×, High Glucose; Gibco, Invitrogen, Scotland, UK) supplemented with $10 \%$ foetal bovine serum (FBS) (Gibco, Invitrogen) and $1 \%$ of antibiotic (penicillin-streptomycin, $10 \mu \mathrm{g} / \mathrm{mL}$, Gibco, Invitrogen), at $37{ }^{\circ} \mathrm{C}$ and $5 \% \mathrm{CO}_{2}$. Prostate cancer cell lines, HBMEC and PNT-1 cells were maintained in Roswell Park Memorial Institute1640 medium (RPMI, Gibco, Invitrogen) and hDFb190 cells were maintained in Minimum Essential Medium Eagle (MEM) Alpha Modifications ( $\alpha$-MEM, Gibco, Invitrogen), both media were supplemented with $10 \%$ FBS and antibiotics, as described.

\subsection{Cell viability and proliferation assays}

The sulphorhodamine B assay (SRB, TOX-6; Sigma-Aldrich Corp. St. Louis, MO, USA) was used to assess cell viability, according to the manufacturer's recommendations. Briefly, cells were plated into 96-well plates at a density of $1.5 \times 10^{4}, 2 \times 10^{4}$ and $1.3 \times 10^{4}$ cells/well for MDA-MB-231, MDA-MB-468 and MCF7 respectively, $8 \times 10^{3}$ cells/well for DU145 and 22RV1, $5 \times 10^{3}$ cells/ well for SW1088, U251 and HBMEC and $1 \times 10^{4}$ cells/well for PNT1, HB4a and hDFb190 and allowed to adhere overnight in complete medium. The effect of the studied propolis ethanol extract on cell number (total biomass) was determined upon P10.EE treatment $(0.005-0.1 \mathrm{mg} / \mathrm{mL})$ at 24 and 48 hours. Cell proliferation was measured using the 5-bromo-2'-deoxyuridine (BrdU) Cell Proliferation Assay kit (Cell Proliferation ELISA; Roche Diagnostics, Pleasanton, CA, USA), as described by Miranda-Goncalves et al. (2013). Briefly, MDA-MB-231, DU145 and HBMEC cells were plated into 96-well plates (density of $1.5 \times 10^{4}$ and $8 \times 10^{3}$ cells/well), and were treated with 0.0075 , $0.015,0.0035$ and $0.007 \mathrm{mg} / \mathrm{L}$ and also 0.004 and $0.008 \mathrm{mg} / \mathrm{mL}$ of P10.EE, respectively, during 24 hours in medium without FBS. Subsequently, cells were incubated with BrdU. Results are expressed as mean \pm SEM of three independent experiments, each in triplicate.

\subsection{Metabolism assay (glucose and lactate measurement)}

MDA-MB-231 $\left(3 \times 10^{4}\right.$ cells/well $)$ and DU145 $\left(2.8 \times 10^{4}\right.$ cells/ well) cells were seeded in 48-well plates and allowed to adhere overnight in complete medium. Then, cells were treated with the $\mathrm{IC}_{50}$ value of P10.EE for 48 hours. The culture medium of the cells was collected after 24 and 48 hours and glucose and lactate were quantified using commercial kits (Roche and Spinreact, respectively), according to manufacturers' protocols. Also, the total protein (expressed as total biomass) was assessed using the SRB assay, for these time points. Results 
are normalized for control and expressed as total $\mu \mathrm{g} / \mathrm{total}$ biomass.

\subsection{Apoptosis and cell cycle assays}

Annexin (BD Biosciences) and propidium iodide (Sigma) were used to determine the apoptotic and necrotic cell population. Briefly, MDA-MB-231 and DU145 cells were seeded in T25 flasks $\left(1 \times 10^{5}\right.$ cells $\left./ \mathrm{mL}\right)$, and allowed to adhere overnight in complete medium. Then, after 48 hours of treatment with the $\mathrm{IC}_{50}$ value of P10.EE, cells were collected and Annexin V/PI staining was performed according to the manufacturer's instructions. The percentage of cell death was assessed by flow cytometry (LSRII model, BD Biosciences) with a total of 20,000 events. The results were analyzed using the FlowJo software (version 7.6; Tree Star). For cell cycle study, cells were seeded and treated at the conditions previously described after 6 hours of serum starvation. After treatment, cells were collected and stained as previously described (Martinho et al., 2012). Cell cycle analysis was assessed by flow cytometry with a total of 15,000 events, and the results were analyzed using the FlowJo software (version 7.6; Tree Star). Results are expressed as mean \pm SEM of three independent experiments, each in triplicate.

\subsection{Wound healing assay}

MDA-MB-231 and DU145 cells were seeded in a six-well culture plate, at a density of $1 \times 10^{6}$ cells/well and cultured to at least $95 \%$ of confluence. Wound-healing assay was performed as previously reported by Miranda-Goncalves et al. (2013). Cells were treated with the IC $_{50}$ value of P10.EE for 48 hours and specific scratching sites of the wound areas were photographed at 0 , 24 and 48 hours. The relative migration distances were analyzed using the software QWound (developed at ICVS by the biomedical engineering team) and data were expressed in \% of migration. Results are expressed as mean \pm SEM of three independent experiments, each in triplicate.

\subsection{Chicken Chorioallantoic Membrane (CAM) assay}

The CAM assay was performed as previously described by Miranda-Goncalves et al. (2013). Briefly, on the 10th day of development, treatments with $0.1 \mathrm{mg} / \mathrm{mL}$ of P10.EE in PBS $1 \mathrm{X}$ and respective controls ( $1 \% \mathrm{DMSO})$ were performed. Then, the effect of P10.EE on CAM vascularization was assessed on days 14 and 17 of development. The number of blood vessels was counted in the area inside the ring placed previously in the CAM, using ImageJ software (version 1.41; National Institutes of Health, available on the Internet at http://rsb.info.nih.gov/nihimage/).

\subsection{Western blotting}

Propolis-treated MDA-MB-231 and DU145 cell lysates were separated by SDS-PAGE and transferred to nitrocellulose membrane as formerly described by Miranda-Goncalves et al. (2013). To analyze the influence of P10.EE on protein expression, membranes were incubated overnight at $4{ }^{\circ} \mathrm{C}$ with the primary polyclonal antibodies for monocarboxylate transporter 1 (MCT1, 1:500 dilution, sc-365501, Santa Cruz Biotechnology); monocarboxylate transporter 4 (MCT4, 1:2000 dilution, sc50329, Santa Cruz Biotechnology); CD147 (1:200 dilution, sc71038, Santa Cruz Biotechnology); hypoxia-inducible factor 1 $\alpha$ (HIF-1 $\alpha, 1: 1000$ dilution, 610958, BD Bioscience); pyruvate dehydrogenase kinase (PDK, 1:2000 dilution, ab110025, Abcam); lactate dehydrogenase (LDH-A, 1:2000 dilution, ab101562, Abcam); pyruvate dehydrogenase (PDH, 1:300 dilution, ab67592, Abcam); glucose transporter 1 (GLUT1, 1:800 dilution, ab15309500, Abcam); carbonic anhydrases IX (CAIX, 1:1000 dilution, ab15086, Abcam); hexokinases II (HKII, 1:2000 dilution, ab104836, Abcam); CD44 (1:500 dilution, MCA2726, AbDSerotec). Signals of the bound antibodies were detected by chemiluminescence (Supersignal West Femto kit, Pierce, Thermo Scientific). $\beta$-Actin was used as loading control at 1:300 dilution (sc1616; Santa Cruz Biotechnology).

\subsection{Drug combination studies}

MDA-MB-231 and DU145 cells were seeded into 96-well plates at a density of $1.5 \times 10^{4}$ and $8 \times 10^{3}$ cells/well, respectively. Treatments with (i) paclitaxel $(0.01-1 \mu \mathrm{M})$, (ii) P10.EE $(0.005-0.1 \mathrm{mg} /$ $\mathrm{mL}$ ) and (iii) paclitaxel $(0.01-1 \mu \mathrm{M})+$ P10.EE (0.0075 or $0.0035 \mathrm{mg} /$ $\mathrm{mL}$ ) were done for 48 hours. Additionally, cells were also pretreated with P10.EE ( 0.0075 or $0.0035 \mathrm{mg} / \mathrm{mL}$ ) for 24 hours, followed by 24 hours of treatment with paclitaxel $(0.01-1 \mu \mathrm{M})$ but no P10.EE. The effect of the drugs on cell viability (total cell biomass) was evaluated with the SRB assay, as described above.

\subsection{Statistical analysis}

Results were expressed as mean \pm SEM and statistically analyzed using the GraphPad Prism 5 software. Unpaired t-test was performed to compare two groups. Significance was considered as $\mathrm{p} \leq 0.05$.

\section{Results}

\subsection{Phenolic characterization of P10.EE by UV-visible spectrophotometry and HPLC-DAD-ESI-MS ${ }^{n}$}

Considering that phenolic compounds are major chemical components of propolis (Bankova et al., 2000), as well as central agents on its beneficial properties (Viuda-Martos, Ruiz-Navajas, Fernandez-Lopez, \& Perez-Alvarez, 2008), we first estimated the total amounts of phenolic compounds and flavonoids in the P10.EE extract by spectrophotometric assays, followed by the elucidation of its main phenolic constituents through HPLCDAD-ESI-MS ${ }^{\mathrm{n}}$ analysis. The spectrophotometric analysis showed that P10.EE is enriched in phenolic components, containing a total amount of phenolics of $252.42 \pm 13.44 \mathrm{mg}$ quercetin equivalent/g extract and a total amount of flavonoids of $51.26 \pm 2.39 \mathrm{mg}$ quercetin equivalents/g extract.

Further analysis of P10.EE sample by HPLC-DAD-ESI-MS ${ }^{n}$ allowed the identification of the main phenolic compounds, which enclose the flavonoids pinocembrin ([M-H $]^{-}$at $m / z 255$, fraction 15$)$, chrysin $\left([\mathrm{M}-\mathrm{H}]^{-}\right.$at $m / z$ 253, fraction 16$)$, pinobanksin $\left([\mathrm{M}-\mathrm{H}]^{-}\right.$at $m / z$ 271, fraction 8 ) and pinobanksin-3-O-acetate $\left([\mathrm{M}-\mathrm{H}]^{-}\right.$at $\mathrm{m} / \mathrm{z} 313$, fraction 17$)$, as well as the phenolic acids 
caffeic acid ([M-H] $]^{-}$at $m / z$ 179, fraction 1$), p$-coumaric acid ([M$\mathrm{H}^{-}$at $m / z$ 163, fraction 2$)$ and ferulic acid ([M-H $]^{-}$at $m / z 193$, fraction 3) (see Supplementary Table S1 and Fig. S1). Additionally, P10.EE is also enriched in esterified derivatives of caffeic acid and $p$-coumaric acid, with particular prevalence of the first one. The main caffeic acid derivatives comprised two isomers of isoprenyl ester ([M-H] $]^{-}$at $m / z$ 247, fractions 12 and 13), one benzyl ester $\left([\mathrm{M}-\mathrm{H}]^{-}\right.$at $\mathrm{m} / \mathrm{z} 269$, fraction 14$)$, the phenylethyl ester derivative $\left([\mathrm{M}-\mathrm{H}]^{-}\right.$at $m / z$ 283, fraction 17$)$ and the dimethylester derivative ([M-H] $]^{-}$at $m / z$ 207, fraction 4$)$, while the main detected $p$-coumaric acid derivative appeared as a methyl ester $\left([\mathrm{M}-\mathrm{H}]^{-}\right.$at $\mathrm{m} / \mathrm{z} 177$, fraction 7$)$.

\subsection{Effect of P10.EE in the viability of different cells}

In the screening performed with different cells, P10.EE generally affected the viability of the seven tested cancer cell lines, with the lowest effect for the two normal cell lines and the fibroblast cells, which demonstrate that they are less sensitive to P10.EE (Table 1 and see Supplementary Fig. S2). We thus chose two cell lines for subsequent studies: DU145, the most sensitive cell line and MDA-MB-231 which is also very sensitive to P10.EE but presents an IC $_{50}$ twofold higher than the IC $\mathrm{I}_{50}$ value calculated for DU145 cells. The concentrations of propolis used were the $\mathrm{IC}_{50}$ values at 48 hours.

\subsection{In vitro effect of P10.EE on breast and prostate cancer cells}

The antitumoural effect of P10.EE on breast and prostate cancer cells was characterized on cell proliferation, cell cycle and death, migration and metabolism. In Fig. 1A, it is possible to observe that $\mathrm{IC}_{50} / 2$ and $\mathrm{IC}_{50}$ of P10.EE, promoted a significant reduction in MDA-MB-231 and DU145 cell line proliferation, respectively, compared to the control, with these effects being concentration-dependent. Regarding the effect of P10.EE on cell cycle distribution and cell death it was possible to see (Fig. 1B) that MDA-MB-231 presented a decrease in the cell population of $G_{0} / G_{1}$ phases and $G_{2} / M$ phases which was accompanied with an increase in the cell population of $\mathrm{S}$ phase, for $\mathrm{IC}_{50} / 2$ and $\mathrm{IC}_{50}$, compared to control. Additionally, an increase in cell population of sub-Go phase was observed. However, in DU145 cells, there was a significant increase in the cell population of sub-Go phase with a decrease in the cell population of the $G_{0} /$

\begin{tabular}{|c|c|c|}
\hline \multirow[t]{2}{*}{ Cells } & \multicolumn{2}{|c|}{$\mathrm{IC}_{50}(\mathrm{mg} / \mathrm{mL})$} \\
\hline & $24 \mathrm{~h}$ & $48 \mathrm{~h}$ \\
\hline MDA-MB-231 & 0.034 & 0.015 \\
\hline MDA-MB-468 & 0.022 & 0.011 \\
\hline MCF7 & 0.019 & 0.017 \\
\hline DU145 & 0.028 & 0.007 \\
\hline 22RV1 & 0.023 & 0.01 \\
\hline SW1088 & 0.033 & 0.015 \\
\hline U251 & 0.022 & 0.013 \\
\hline HB4a & 0.046 & 0.046 \\
\hline PNT-1 & 0.043 & 0.033 \\
\hline hDFb 190 & 0.06 & 0.062 \\
\hline
\end{tabular}

$\mathrm{G}_{1}$ phases and a slight increase in the cell population of $\mathrm{S}$ phase, compared to control, being the greatest effect obtained at the highest concentrations. Through the Annexin V/PI assay (Fig. 1C), we observed that P10.EE treatment induced cell death in MDAMB-231 cells by a significant increase in early apoptotic and late apoptotic/necrotic cell population for $0.015 \mathrm{mg} / \mathrm{mL}$, compared to the control. Nevertheless, treatment of DU145 cells with $0.007 \mathrm{mg} / \mathrm{mL}$ of P10.EE only promoted a slight increase in late apoptotic/necrotic cell population.

In what concerns cell migration (Fig. 1D), both concentrations of P10.EE (0.0075 and $0.015 \mathrm{mg} / \mathrm{mL}$ ) significantly decreased the MDA-MB-231 cell migration, compared to the control, this effect being dose-dependent. Additionally, there are significant differences between $0.015 \mathrm{mg} / \mathrm{mL}$ treatment of 24 and 48 hours. In DU145 cells, both concentrations of P10.EE (0.0035 and $0.007 \mathrm{mg} / \mathrm{mL}$ ) significantly decreased the cell migration and this effect seems also to be dose-dependent. Nevertheless, there are no significant differences between the treatment conditions of 24 and 48 hours.

Our results from the effect of P10.EE on metabolic disturbance (Fig. 2A) show that MDA-MB-231 suffered a significant increase in glucose consumption after 24 and 48 hours of treatment with $0.015 \mathrm{mg} / \mathrm{mL}$ P10.EE and in lactate production after 24 hours treatment with $0.015 \mathrm{mg} / \mathrm{mL}$ P10.EE and after $48 \mathrm{~h}$ for both P10.EE concentrations. For DU145 cells there was a significant increase in glucose consumption after 24 and 48 hours of treatment with $0.007 \mathrm{mg} / \mathrm{mL}$ P10.EE, and in lactate production after 48 hours. To further support these results, the expression of several proteins that are important to the glycolytic phenotype was analyzed (Fig. 2B). Consistent with the induction of glycolytic metabolism, an increase in the expression of HIF-1 $\alpha$, PDK, GLUT1, LDH-A and CAIX, was observed in MDA-MB-231 cells treated with P10.EE. Nevertheless, there were no alterations in the expression of MCT4, MCT1 and their chaperones (CD147 and CD44). For DU145 cells no alterations were observed in the expression of the same proteins.

Additionally, the effect of the combination of P10.EE and paclitaxel was assessed on MDA-MB-231 and DU145 cell viability. For MDA-MB-231 cells (Fig. 3A) treated with the combination of P10.EE and paclitaxel for 48 hours, there was a decrease in the $\mathrm{IC}_{50}$ value $(0.025 \mu \mathrm{M})$. Furthermore, when cells were first exposed to the $\mathrm{IC}_{50} / 2$ of P10.EE for 24 hours and then treated for additional 24 hours with different concentrations of paclitaxel, it was possible to see a higher potentiation of paclitaxel effect ( $\left.\mathrm{IC}_{50} 0.014 \mu \mathrm{M}\right)$. In DU145 cells (Fig. 3B) treated with the combination of P10.EE and paclitaxel for 48 hours it was seen that P10.EE potentiated the effect of paclitaxel, decreasing its $\mathrm{IC}_{50}$ value $\left(3.7 \mathrm{e}^{-5} \mu \mathrm{M}\right)$. When cells were pre-exposed to P10.EE, an increase in the $\mathrm{IC}_{50}$ value $(0.08 \mu \mathrm{M})$ was observed and thus there was no enhancement of the effect of paclitaxel.

\subsection{Effect of P10.EE on angiogenesis}

Regarding the in vitro results (Fig. 4A) it is possible to observe that HBMEC is sensitive to propolis over time, with the $\mathrm{IC}_{50}$ values being $0.015 \mathrm{mg} / \mathrm{mL}$ for 24 hours and $0.008 \mathrm{mg} / \mathrm{mL}$ for 48 hours. In what concerns proliferation, P10.EE at 0.004 and $0.008 \mathrm{mg} / \mathrm{mL}$ significantly decreased the proliferative capacity of the cells, being the greatest effect obtained for the highest concentration tested. 
A

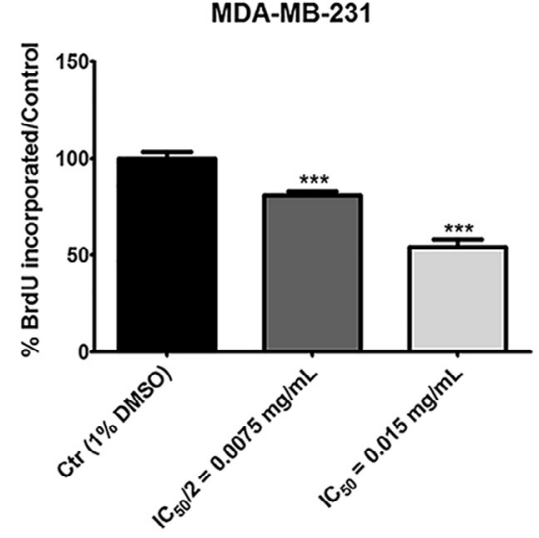

C

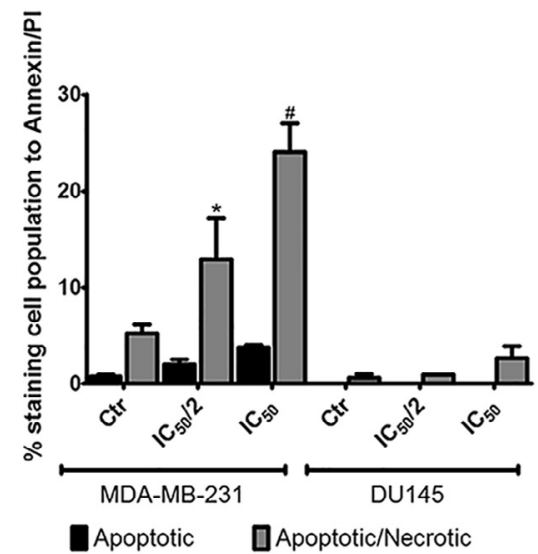

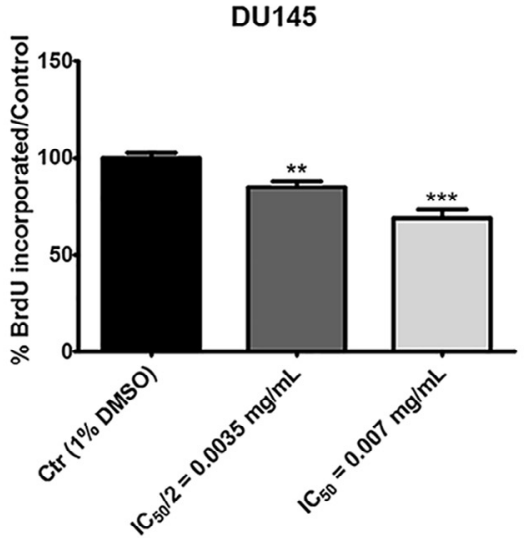

D

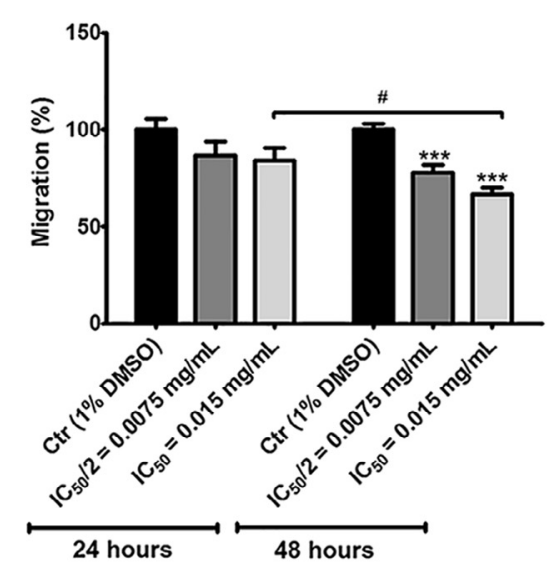

B

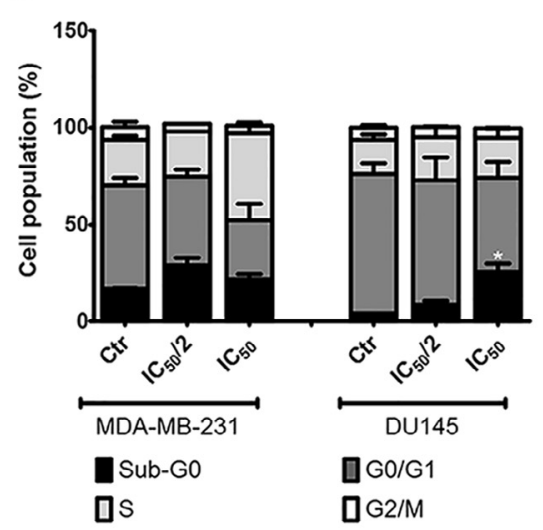

DU145

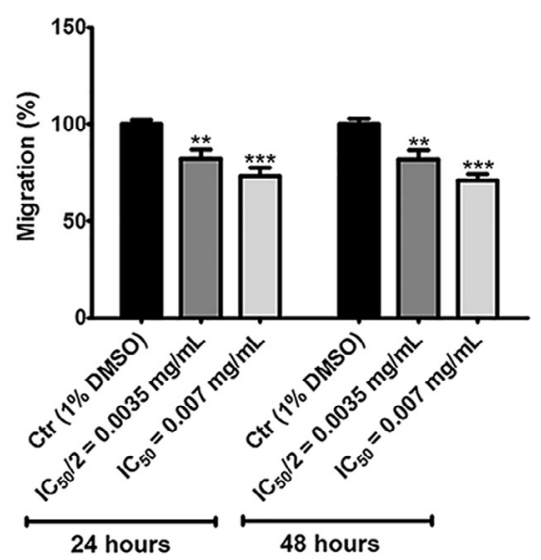

Fig. 1 - Effect of P10.EE on breast and prostate cancer cell behaviour. (A) The effect of P10.EE on cell proliferation was determined by BrdU assay. P10.EE decreased significantly the proliferative capacity of MDA-MB-231 and DU145 cells after $24 \mathrm{~h}$ treatment. ${ }^{* *} \mathrm{p} \leq 0.01 ;{ }^{* * *} \mathrm{p} \leq 0.001$, compared to control. (B) Cell cycle distribution was determined by flow cytometry of iodide propidium stained cells after $48 \mathrm{~h}$ of P10.EE treatment, at corresponding IC $\mathrm{S}_{50}$ values, for MDA-MB-231 and DU145. P10.EE induced a decrease in G0/G1 with an increase in S phase population in MDA-MB-231 and significantly increased the sub-G0 phase population in DU145 cells. " $\mathrm{p} \leq 0.05$, compared to controls. (C) Cell death analysis was performed by Annexin V/PI (flow cytometry) after $48 \mathrm{~h}$ of treatment with IC $_{50} / 2$ and IC 50 values of P10.EE. In MDA-MB-231 cells a significant increase in cell death was observed whereas there were no differences for DU145. ${ }^{*, *} \mathrm{p} \leq 0.05$, compared to control. (D) Cell migration was determined by the scratch-wound healing assay. In MDA-MB-231 cells, only $48 \mathrm{~h}$ of P10.EE treatment decreased cell migration significantly. In DU145 cells, both concentrations of P10.EE significantly decreased the cell migration. ${ }^{* *} p \leq 0.01 ;{ }^{* * *} p \leq 0.001$, compared to control and ${ }^{\#} \mathrm{p} \leq 0.05$, comparing 24 and $48 \mathrm{~h}$ treatment conditions. All the results are expressed as mean \pm SEM of at least three independent experiments.

Using the in vivo CAM assay (Fig. 4B), it is possible to observe that $0.1 \mathrm{mg} / \mathrm{mL}$ of P10.EE significantly affects the naturally occurring neovascularization from existing vessels in the CAM. In fact, a significant decrease in the sprouting vessels is visible ex ovo, as well as changes in morphology (decreased vessel width) compared to the control.

\section{Discussion}

In recent years, the understanding of tumour biology has significantly changed the paradigm of cancer therapy and allowed the identification of new therapeutic targets, with development of new methods and therapeutic agents (Luo, Solimini, \& Elledge, 2009). Over the years, natural products have been used as promising sources for discovery of new pharmaceutical agents (Bankova, 2007; Manach et al., 2009). Propolis, has been widely studied for its biological properties (Fokt et al., 2010), especially antitumour activity (Barlak et al., 2011; Chan et al., 2012; Chuu et al., 2012; Lofty, 2006; Umthong et al., 2011; Valente et al., 2011; Wu et al., 2011); nevertheless, there are only two studies exploring Portuguese propolis with this purpose (Valença et al., 2013; Valente et al., 2011).

In the present study we aimed to analyze the chemical composition and the antitumoural activity of a Portuguese propolis sample collected in Pereiro, an apiary located in the district of Guarda, Beira Alta.

Propolis is composed of a great number of phenolic compounds, with flavonoids and phenolic acids being the most important classes. Results from the spectrophotometric analy- 
A
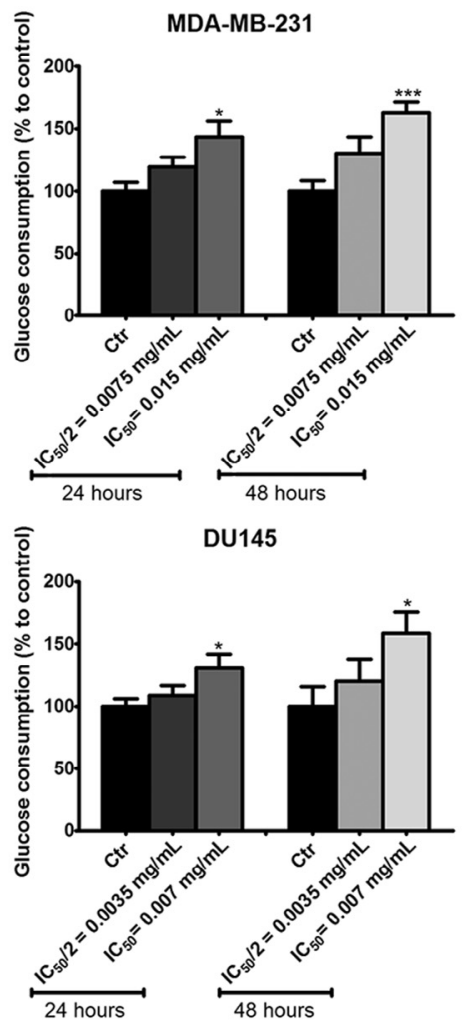
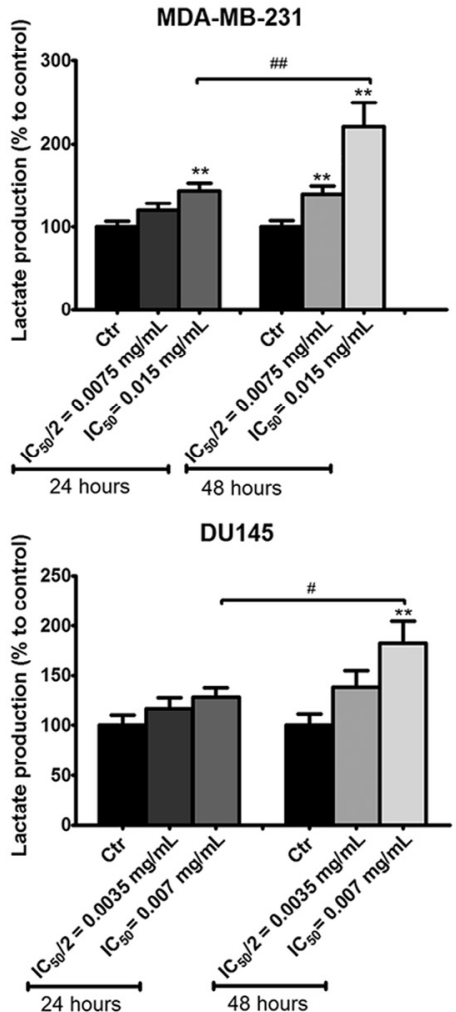
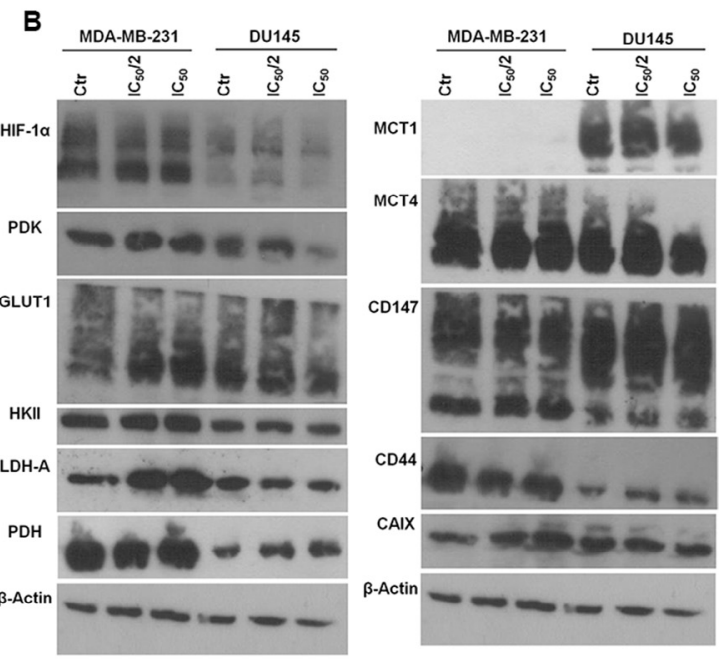

Fig. 2 - Effect of P10.EE on the glycolytic metabolism of breast and prostate cancer cell lines. (A) In the MDA-MB-231 cells, $0.015 \mathrm{mg} / \mathrm{mL}$ P10.EE significantly increased glucose consumption and lactate production after 24 and $48 \mathrm{~h}$ treatment. In DU145 cells, P10.EE at $0.007 \mathrm{mg} / \mathrm{mL}$ significantly increased glucose consumption after 24 and $48 \mathrm{~h}$ and only after $48 \mathrm{~h}$ did it significantly increase lactate production. ${ }^{*} \mathrm{p} \leq 0.05 ;{ }^{* *} \mathrm{p} \leq 0.01 ;{ }^{* * *} \mathrm{p} \leq 0.001$ compared to control and ${ }^{\# p} \leq 0.05 ;{ }^{* \#} \mathrm{p} \leq 0.01$, comparing 24 and $48 \mathrm{~h}$ treatment conditions. Results are expressed as mean \pm SEM of at least three independent experiments, each in triplicate. (B) Characterization of the expression of several important proteins to the glycolytic metabolism in breast and prostate cancer cell lines. Western blot analysis of HIF-1 $\alpha$, PDK, GLUT1, HKII, LDH-A, PDH, MCT1, MCT4, CD147, CD44, CAIX shows different levels of expression in both cell lines. The molecular weights $(\mathrm{kDa})$ are the following: $120 \mathrm{kDa}$ for HIF-1 $\alpha, 44 \mathrm{kDa}$ for PDK, $55 \mathrm{kDa}$ for GLUT1, $102 \mathrm{kDa}$ for HKII, $37 \mathrm{kDa}$ for LDH-A, $43 \mathrm{kDa}$ for PDH, $43 \mathrm{kDa}$ for MCT1, $43 \mathrm{kDa}$ for MCT4, $52 \mathrm{kDa}$ for the highly glycosylated and $43 \mathrm{kDa}$ for low glycosylated form of CD147, $90 \mathrm{kDa}$ for CD44, $55 \mathrm{kDa}$ for CAIX.

sis of total flavonoid and total phenolic content show that P10.EE has a high concentration of phenolic compounds and flavonoids, identical to those found in other propolis samples of different geographic origin, more specifically samples of European countries (Barlak et al., 2011; Mavri et al., 2012; Miguel et al., 2010; Moreira et al., 2008). As already referred, poplar propolis samples are composed mainly of the flavonoids pinocembrin, pinobanksin, chrysin and galangin, the phenolic acids caffeic acid, ferulic acid and cinnamic acid, and their esters, whereas samples of Brazilian propolis, also often studied, are composed majorly of prenylated phenylpropanoids, prenylated $p$-coumaric acids, acetophenones, diterpenic acids, caffeoyl quinic acids (Bankova, 2005a; Bankova et al., 2000; Falcão et al., 2010, 2012). In this study, the HPLC-DAD-ESI$\mathrm{MS}^{\mathrm{n}}$ analysis allowed to confirm that Pereiro's propolis phenolic profile corresponds to that of a temperate zone type ("poplar"), as the flavonoids pinocembrin and chrysin plus several phenolic acids and their derivatives (all known to be predominant in poplar propolis), were eluted in the major HPLC fraction (Falcão et al., 2010, 2012; Pellati, Orlandini, Pinetti, \& Benvenuti, 2011).
Once the principal compounds of the P10.EE were elucidated, we focused our interest in its antitumoural activity. With the screening performed in different cells, we can consider that P10.EE affects the viability of the seven tested cancer cell lines, with the lowest effect for the two normal cell lines and the fibroblast cells, with these results being in accordance to the literature (Chuu et al., 2012; Pratsinis, Kletsas, Melliou, \& Chinou, 2010; Umthong et al., 2011; Wu et al., 2011; Xuan et al., 2014). Umthong et al. (2011) also showed that the hexane extract of Trigona laeviceps propolis from Thailand has a high cytotoxic effect against five tested cancer cell lines (Chago, KATO-III, SW620, BT474 and Hep-G2) but not against the normal cell lines used (HS27 fibroblast and CH-liver). Despite the variability in propolis chemical composition, it is well known that samples of different geographic origins or even isolated compounds can display identical biological activities (Fokt et al., 2010). Ishihara, Naoi, Hashita, Itoh, and Suzui (2009) showed that the viability of different human colon carcinoma cell lines (HCT116, HT29 and SW480) decreased in a dose-dependent way by ethanol extracts of Chinese and Brazilian propolis. Ethanol extracts of propolis from Brazil (Li et al., 2007) and Poland (Szliszka et al., 

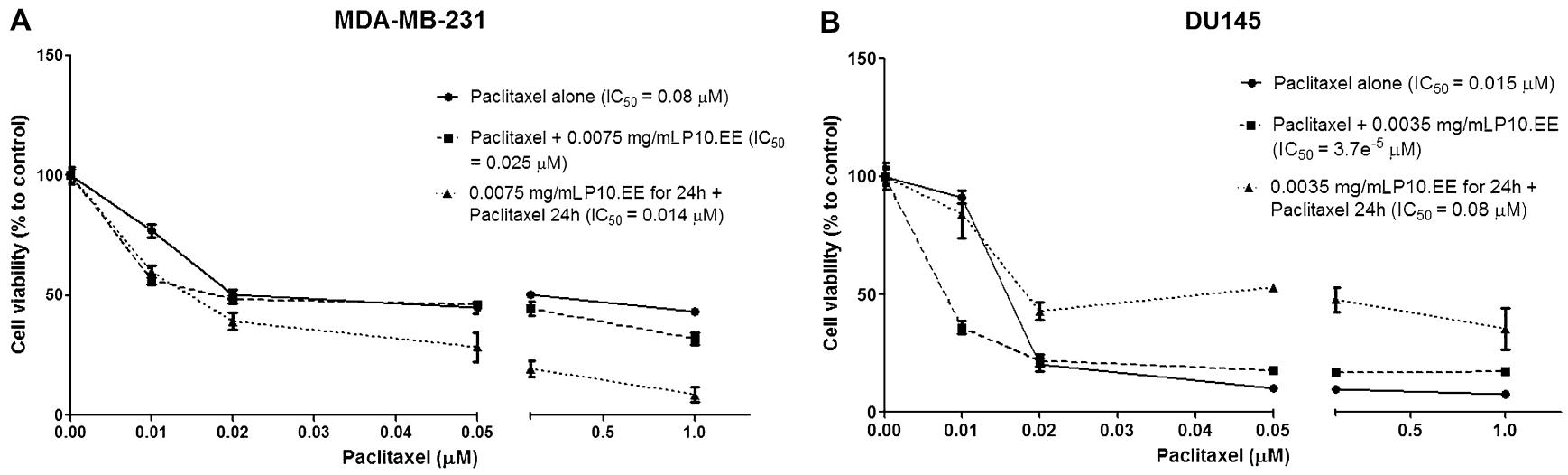

\begin{tabular}{cccc}
\hline & \multicolumn{3}{c}{ IC $_{50}(\boldsymbol{\mu M})$} \\
\cline { 2 - 4 } Cells & Paclitaxel & $\begin{array}{r}\text { Paclitaxel }+ \\
\text { P10.EE }(48 \mathrm{~h})\end{array}$ & $\begin{array}{c}\text { P10.EE for 24h + } \\
\text { Paclitaxel 24h }\end{array}$ \\
\cline { 2 - 4 } MDA-MB-231 & 0.08 & 0.025 & 0.014 \\
& & & 0.08 \\
\hline
\end{tabular}

Fig. 3 - Effect of P10.EE on paclitaxel treatment of breast (A) and prostate (B) cancer cell lines, determined by SRB assay at $48 \mathrm{~h}$. Growth curves for paclitaxel and P10.EE in monotherapy were compared with the different types of combination, and the IC 50 values were calculated (table). (A) For MDA-MB-231 cells, both types of treatment decreased the IC 50 value compared to paclitaxel monotherapy, being the effect more significant when cells were pre-treated with P10.EE for $24 \mathrm{~h}$ and then treated for additional $24 \mathrm{~h}$ with different concentrations of paclitaxel. (B) For DU145 cells, a decrease in the IC 50 value was only obtained with the mixture of the drugs. Results are expressed as mean of three independent experiments, each in triplicate.

2011a) decreased the viability of the DU145 prostate cancer cells and a decrease of PC-3 prostate cancer cells viability was promoted by ethanolic extract of Brazilian propolis and dimethyl sulphoxide and water extracts of Turkish propolis (Barlak et al., 2011; Li et al., 2007).

From the above results, two cell lines were selected for further studies on the basis of the greater effect of P10.EE after 48 hours: DU145 and MDA-MB-231. Since it is known that propolis can render its antitumoural effect by different mechanisms (Chan et al., 2012), we analyzed the effect of P10.EE on proliferation, cell cycle, apoptosis, migration and metabolism of the chosen cancer cell lines and also propolis effect on angiogenesis by using an endothelial cell line and the CAM in vivo model. The results show that besides leading to a dose-dependent decrease in MDA-MB-231 cell proliferation, P10.EE also affected its cell cycle since it appears to promote a cell cycle arrest at the $\mathrm{S}$ phase. There was a significant increase in the cell population of $S$ phase with a concurrent decline in the $G_{0} / G_{1}$ and $\mathrm{G}_{2} / \mathrm{M}$ phases. Regarding cell death, P10.EE induced cell death in MDA-MB-231 cells by a significant increase in early apoptotic and late apoptotic/necrotic cell population. These results are in agreement with the observations of Wu et al. (2011), where the authors showed that CAPE promoted a decrease in MDAMB-231 proliferation by NF- $\mathrm{KB}$ down-regulation, an $\mathrm{S}$ phase cell cycle arrest by an increase in the expression of p21 and p27 proteins and a decrease in the expression of Rb, TP53, cyclins G1, D1, E1 and C, CDK2 and apoptosis by a decreased expression of anti-apoptotic proteins. Another study showed that cell proliferation of TW2.6 human oral squamous cell carcinoma cells was suppressed by CAPE through a decrease in G1 phase cell population, an increase in G2/M phase cell population and apoptosis (Kuo et al., 2013). CAPE was also shown to inhibit the proliferation of the colorectal cell line SW480 by decreasing the $\beta$-catenin, c-myc and cyclin D1 expression (He et al., 2006). Sulaiman et al. (2012) showed that Iraqi propolis promotes HL60 cells apoptosis by down-regulating $\mathrm{Bcl}-2$ proteins and activating Bax proteins.

Concerning DU145 cells, P10.EE significantly decreased the proliferative capacity of the cells in a dose-dependent way; however, the effect of P10.EE in DU145 cell cycle differs greatly from the effect on MDA-MB-231 cells. Propolis-treated DU145 cells present a significant increase in the cell population of sub$\mathrm{G}_{0}$ phase, possibly corresponding to an increase of senescence or apoptotic state cell population, with a slight increase in the cell population of $\mathrm{S}$ phase and a decrease in the cell population of the $G_{0} / G_{1}$ phases. Such results on the anti-proliferative effects of P10.EE in DU145 cells are in agreement with the study of Chuu et al. (2012), which shows that CAPE treatment decreased cell proliferation by inhibition of p70S6K and other Aktrelated protein signalling networks. Nevertheless, in contrast to our results, the authors showed that CAPE significantly reduces cells in the S-phase and increases cells in $G_{0} / G_{1}$ population phases. Additionally, Li et al. (2007) showed that ethanol extracts of Brazilian propolis regulate the expression of cyclin D1, B1 and cyclin dependent kinase (CDK) as well as p21 protein, affecting the proliferation of human prostate cancer cells. Con- 

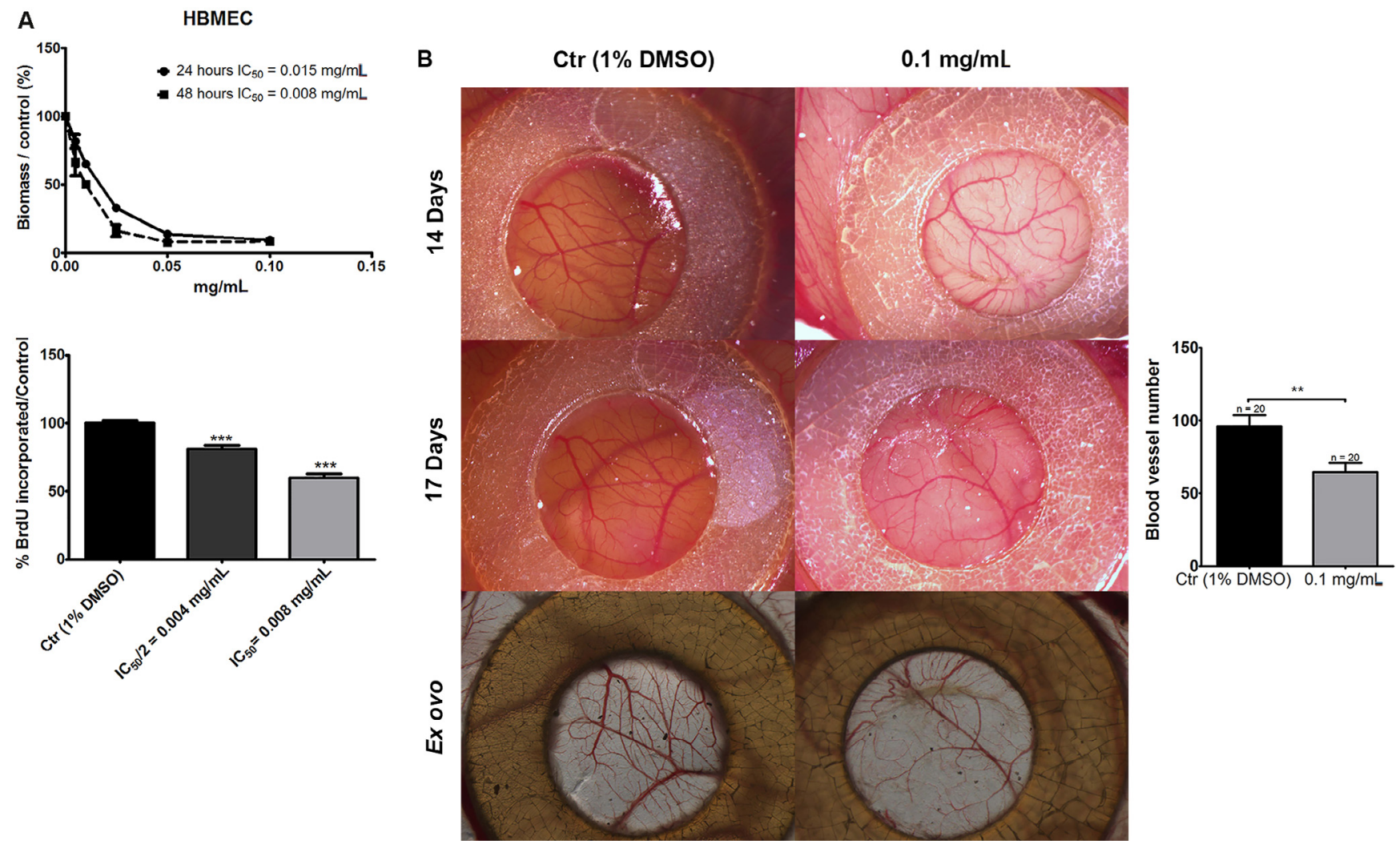

Fig. 4 - Antiangiogenic effect of P10.EE. (A) Effect of P10.EE on HBMEC cell viability and proliferation. P10.EE induced a reduction of HBMEC cell viability and decreased significantly its proliferative capacity after $24 \mathrm{~h}$ treatment. ${ }^{* * *} \mathrm{p} \leq 0.001$, compared to control. Results are expressed as mean \pm SEM of at least three independent experiments, each in triplicate. (B) In vivo effect of P10.EE on the CAM vascularization of the chicken embryo. CAM was photographed on the 14th day (in ovo) and 17th (in and ex ovo) of development (12.5× magnification). P10.EE treatment affects the natural sprouting of new vessels from the existing vessels, compared to control. Blood vessels were counted ex ovo, as described in the Materials and Methods section. P10.EE significantly decreased the number of vessels, compared with the control group (control group $\mathrm{n}=20 ; 0.1 \mathrm{mg} / \mathrm{mL}$ group $\mathrm{n}=20) .{ }^{* *} \mathrm{p} \leq 0.01$, compared to control.

cerning the effects of P10.EE on DU145 cell death, there was a small induction in late apoptotic/necrotic cell population, again in accordance to the literature (Szliszka et al., 2011a, 2011b). In those studies it was demonstrated that propolis, more specifically from Brazil, sensitizes DU145 cells to a TRAIL-induced death, enhances the expression of TRAIL-R2 and decreases the activity of NF- $\mathrm{KB}$ in LNCaP cells. Also, a significant activation of caspase- 8 and caspase-3, as well as disruption of the mitochondrial membrane potential, was observed in a cotreatment with TRAIL and artepillin C (Szliszka et al., 2011a, 2011b; Szliszka, Zydowicz, Mizgala, \& Krol, 2012). Additionally, in both cell lines P10.EE significantly decreased the cells' migratory capacity in a dose-dependent way. Similar results were obtained by Lee et al. (2008) and Hwang et al. (2006) with CAPE, which significantly inhibited the expression of MMP-2, MMP-9 and NF- $\mathrm{\kappa B}$ promoting an effective suppression in cell motility and migration.

To the best of our knowledge, studies on the effect of propolis on glycolytic metabolism of cancer cells are scarce, and lacking for Portuguese propolis. The present study shows that P10.EE, at different concentrations, promoted in MDA-MB231 and DU145 cell lines a significant increase in glucose consumption and lactate production rates. In MDA-MB-231 cells, we observed an increased expression of HIF-1 $\alpha$, PDK, GLUT1, LDH-A and CAIX, which is consistent with induction of glycolytic metabolism. Curiously, these results are in agreement to the ones obtained by Ueda, Hayashibara, and Ashida (2013), although some caution should be taken in the comparison of the two studies as the latter authors tested normal cells instead of cancer cells, as in the present study. Additionally, a recent study reported that the cytotoxicity effect of a Portuguese propolis sample from Angra do Heroísmo (Azores) involves disturbance in tumour cell glycolytic metabolism, seen by a decrease in glucose consumption and lactate production but in a different cancer model (Valença et al., 2013). We believe that these differences among the studies could be the result of the use of different propolis samples and cell models.

In order to evaluate the effect of P10.EE on angiogenesis, both in vitro and in vivo studies were performed. Using a brain endothelial cell line (HBMEC), we observed that P10.EE significantly induced a dose- and time-dependent reduction in cell viability and its proliferative capacity after 24 hours of treatment. These results are also in agreement with the literature (Ahn et al., 2007; Izuta et al., 2009; Kunimasa et al., 2011; Park, Ohta, Kumazawa, Jun, \& Ahn, 2014). Izuta et al. (2009) showed that VEGF-induced human umbilical vein endothelial cells 
(HUVEC) proliferation was significantly suppressed by Chinese red propolis and CAPE. Ahn et al. (2007) showed that Brazilian propolis could significantly reduce the number of newly formed vessels and suppress the proliferation of the HUVEC in vitro and Kunimasa et al. (2011) proposed that the antiangiogenic effect of propolis was essentially mediated through inducing apoptosis in tube-forming endothelial cells through the inactivation of the survival signal ERK1/2.

In the in vivo CAM assay, P10.EE decreased the number of naturally occurring neovascularization from existing vessels. These results are in agreement with the observations of Daleprane et al. (2012) regarding the evidence that polyphenols have antiangiogenic effects in vitro and ex and in vivo, by inhibiting effectively VEGF gene expression.

Taking into account the similarities between our results and the ones of the literature, we hypothesize that the antitumoural and antiangiogenic effects of Pereiro propolis may be mediated in part by the effect of the most abundant compounds in the sample, caffeic acid and its derivative CAPE.

Additionally, a combinatory drug study was performed to assess the influence of P10.EE on paclitaxel activity in both cancer cell lines previously selected. In general, we observed that using different conditions of treatment - in terms of concentrations of P10.EE and paclitaxel - the decrease of the MDA-MB-231 and DU145 cell viability by paclitaxel was potentiated. Similarly, Tolba et al. (2013) observed that CAPE enhances the antiproliferative and cytotoxic effects of paclitaxel in prostate cancer.

Overall, apart from the increase in glycolytic metabolism, the results support the use of P10.EE as a candidate for cancer drug development since it affects important characteristics that dictate tumorigenesis - cell proliferation, migration and angiogenesis - while also promoting cancer cell death. Even though the study of Portuguese propolis is still at a very initial stage, this study contributes to its valorization as a natural resource and opens new perspectives for its exploitation in pharmacology or in the functional food area through the conception of new propolis-based products that will improve health and likely prevent some chronic diseases.

\section{Conflict of interest}

The authors declare that there are no conflicts of interest.

\section{Acknowledgements}

This work was supported by the Life and Health Sciences Research Institute, University of Minho, Portugal, and Fundação para a Ciência e Tecnologia (FCT) (SFRH/BD/51997/2012 to V.M.G.), through Fundo Europeu de Desenvolvimento Regional-QRENCOMPETE, projects PTDC/AAC-CLI/098308/2008 and PTDC/AACCLI/118092/2010 and also CERNAS (project PEst-OE/AGR/UI0681/ 2011).

\section{Appendix: Supplementary Material}

Supplementary data to this article can be found online at doi:10.1016/j.jff.2014.09.009.

\section{REFEREN C E S}

Ahn, M. R., Kunimasa, K., Ohta, T., Kumazawa, S., Kamihira, M., Kaji, K., Uto, Y., Hori, H., Nagasawa, H., \& Nakayama, T. (2007). Suppression of tumor-induced angiogenesis by Brazilian propolis: Major component artepillin C inhibits in vitro tube formation and endothelial cell proliferation. Cancer Letters, 252, 235-243.

Amoros, M., Simoes, C. M., Girre, L., Sauvager, F., \& Cormier, M. (1992). Synergistic effect of flavones and flavonols against herpes simplex virus type 1 in cell culture. Comparison with the antiviral activity of propolis. Journal of Natural Products, 55, 1732-1740.

Bankova, V. (2005a). Chemical diversity of propolis and the problem of standardization. Journal of Ethnopharmacology, 100, 114-117.

Bankova, V. (2005b). Recent trends and important developments in propolis research. Evidence-based Complementary and Alternative Medicine, 2, 29-32.

Bankova, V. (2007). Natural products chemistry in the third millennium. Chemistry Central Journal, 1, 1.

Bankova, V., de Castro, S. L., \& Marcucci, M. C. (2000). Propolis: Recent advances in chemistry and plant origin. Apidologie, 31, 3-15.

Bankova, V., Popova, M., Bogdanov, S., \& Sabatini, A. G. (2002). Chemical composition of European propolis: Expected and unexpected results. Zeitschrift fur Naturforschung. C, Journal of Biosciences, 57, 530-533.

Bankova, V., Popova, M., \& Trusheva, B. (2014). Propolis volatile compounds: Chemical diversity and biological activity: A review. Chemistry Central Journal, 8, 28.

Barlak, Y., Deger, O., Colak, M., Karatayli, S. C., Bozdayi, A. M., \& Yucesan, F. (2011). Effect of Turkish propolis extracts on proteome of prostate cancer cell line. Proteome Science, 9, 74.

Cardoso, S. M., Ribeiro, M., Ferreira, I. L., \& Cristina Rego, A. (2011). Northeast Portuguese propolis protects against staurosporine and hydrogen peroxide-induced neurotoxicity in primary cortical neurons. Food Chem Toxicol, 49, 2862-2868.

Chan, G. C., Cheung, K. W., \& Sze, D. M. (2013). The immunomodulatory and anticancer properties of propolis. Clin Rev Allergy Immunol, 44, 262-273.

Chuu, C. P., Lin, H. P., Ciaccio, M. F., Kokontis, J. M., Hause, R. J., Jr, Hiipakka, R. A., Liao, S., \& Jones, R. B. (2012). Caffeic acid phenethyl ester suppresses the proliferation of human prostate cancer cells through inhibition of p70S6K and Akt signaling networks. Cancer Preventive Research, 5, 788-797.

Daleprane, J. B., Schmid, T., Dehne, N., Rudnicki, M., Menrad, H., Geis, T., Ikegaki, M., Ong, T. P., Brune, B., \& Abdalla, D. S. (2012). Suppression of hypoxia-inducible factor-1alpha contributes to the antiangiogenic activity of red propolis polyphenols in human endothelial cells. The Journal of Nutrition, 142, 441-447.

Falcão, S. I., Vale, N., Gomes, P., Domingues, M. R., Freire, C., Cardoso, S. M., \& Vilas-Boas, M. (2012). Phenolic profiling of Portuguese propolis by LC-MS spectrometry: Uncommon propolis rich in flavonoid glycosides. Phytochemical Analysis, 24, 309-318.

Falcão, S. I., Vilas-Boas, M., Estevinho, L. M., Barros, C., Domingues, M. R., \& Cardoso, S. M. (2010). Phenolic characterization of Northeast Portuguese propolis: Usual and unusual compounds. Analytical and Bioanalytical Chemistry, 396, 887-897.

Fokt, H., Pereira, A., Ferreira, A. M., Cunha, A., \& Aguiar, C. (2010). How do bees prevent hive infections? The antimicrobial properties of propolis. In A. Mendez-Vilas (Ed.), Current Research, Technology and Education Topics in Applied Microbiology 
and Microbial Biotechnology Microbiology Book Series- Number 2, vol. 1, (pp. 481-493). Badajoz, Spain: Formatex.

Gekker, G., Hu, S., Spivak, M., Lokensgard, J. R., \& Peterson, P. K. (2005). Anti-HIV-1 activity of propolis in CD4(+) lymphocyte and microglial cell cultures. Journal of Ethnopharmacology, 102, 158-163.

Gomez-Caravaca, A. M., Gomez-Romero, M., Arraez-Roman, D., Segura-Carretero, A., \& Fernandez-Gutierrez, A. (2006). Advances in the analysis of phenolic compounds in products derived from bees. Journal of Pharmaceutical and Biomedical Analysis, 41, 1220-1234.

Gordaliza, M. (2007). Natural products as leads to anticancer drugs. Clinical and Translational Oncology, 9, 767-776.

He, Y. J., Liu, B. H., Xiang, D. B., Qiao, Z. Y., Fu, T., \& He, Y. H. (2006). Inhibitory effect of caffeic acid phenethyl ester on the growth of SW480 colorectal tumor cells involves beta-catenin associated signaling pathway down-regulation. World Journal of Gastroenterology, 12, 4981-4985.

Hu, F., Hepburn, H. R., Li, Y., Chen, M., Radloff, S. E., \& Daya, S. (2005). Effects of ethanol and water extracts of propolis (bee glue) on acute inflammatory animal models. Journal of Ethnopharmacology, 100, 276-283.

Hwang, H. J., Park, H. J., Chung, H. J., Min, H. Y., Park, E. J., Hong, J. Y., \& Lee, S. K. (2006). Inhibitory effects of caffeic acid phenethyl ester on cancer cell metastasis mediated by the down-regulation of matrix metalloproteinase expression in human HT1080 fibrosarcoma cells. The Journal of Nutritional Biochemistry, 17, 356-362.

Ishihara, M., Naoi, K., Hashita, M., Itoh, Y., \& Suzui, M. (2009). Growth inhibitory activity of ethanol extracts of Chinese and Brazilian propolis in four human colon carcinoma cell lines. Oncology Reports, 22, 349-354.

Izuta, H., Shimazawa, M., Tsuruma, K., Araki, Y., Mishima, S., \& Hara, H. (2009). Bee products prevent VEGF-induced angiogenesis in human umbilical vein endothelial cells. BMC Complementary and Alternative Medicine, 9, 45.

Kai, H., Obuchi, M., Yoshida, H., Watanabe, W., Tsutsumi, S., Park, Y. K., Matsuno, K., Yasukawa, K., \& Kurokawa, M. (2014). In vitro and in vivo anti-influenza virus activities of flavonoids and related compounds as components of Brazilian propolis (AF-08). Journal of Functional Foods, 8, 214-223.

Kunimasa, K., Ahn, M. R., Kobayashi, T., Eguchi, R., Kumazawa, S., Fujimori, Y., Nakano, T., Nakayama, T., Kaji, K., \& Ohta, T. (2011). Brazilian propolis suppresses angiogenesis by inducing apoptosis in tube-forming endothelial cells through inactivation of survival signal ERK1/2. Evidencebased Complementary and Alternative Medicine, 2010, 870753.

Kuo, Y. Y., Lin, H. P., Huo, C., Su, L. C., Yang, J., Hsiao, P. H., Chiang, H. C., Chung, C. J., Wang, H. D., Chang, J. Y., Chen, Y. W., \& Chuu, C. P. (2013). Caffeic acid phenethyl ester suppresses proliferation and survival of TW2.6 human oral cancer cells via inhibition of akt signaling. International Journal of Molecular Science, 14, 8801-8817.

Lee, K. W., Kang, N. J., Kim, J. H., Lee, K. M., Lee, D. E., Hur, H. J., \& Lee, H. J. (2008). Caffeic acid phenethyl ester inhibits invasion and expression of matrix metalloproteinase in SK-Hep1 human hepatocellular carcinoma cells by targeting nuclear factor kappa B. Clinical Nutrition, 2, 319-322.

Li, H., Kapur, A., Yang, J. X., Srivastava, S., McLeod, D. G., ParedesGuzman, J. F., Daugsch, A., Park, Y. K., \& Rhim, J. S. (2007). Antiproliferation of human prostate cancer cells by ethanolic extracts of Brazilian propolis and its botanical origin. International Journal of Oncology, 31, 601-606.

Lofty, M. (2006). Biological activity of bee propolis in health and disease. Asian Pacific Journal of Cancer Prevention, 7, 22-31.

Luo, J., Solimini, N. L., \& Elledge, S. J. (2009). Principles of cancer therapy: Oncogene and non-oncogene addiction. Cell, 136, 823-837.
Manach, C., Hubert, J., Llorach, R., \& Scalbert, A. (2009). The complex links between dietary phytochemicals and human health deciphered by metabolomics. Molecular Nutrition and Food Research, 53, 1303-1315.

Martinho, O., Granja, S., Jaraquemada, T., Caeiro, C., MirandaGoncalves, V., Honavar, M., Costa, P., Damasceno, M., Rosner, M. R., Lopes, J. M., \& Reis, R. M. (2012). Downregulation of RKIP is associated with poor outcome and malignant progression in gliomas. PLoS ONE, 7, e30769.

Mavri, A., Abramovic, H., Polak, T., Bertoncelj, J., Jamnik, P., Smole Mozina, S., \& Jersek, B. (2012). Chemical properties and antioxidant and antimicrobial activities of Slovenian propolis. Chemistry and Biodiversity, 9, 1545-1558.

Miguel, M. G., Nunes, S., Dandlen, S. A., Cavaco, A. M., \& Antunes, M. D. (2010). Phenols and antioxidant activity of hydroalcoholic extracts of propolis from Algarve, South of Portugal. Food and Chemical Toxicology: An International Journal Published for the British Industrial Biological Research Association, 48, 34183423.

Miranda-Goncalves, V., Honavar, M., Pinheiro, C., Martinho, O., Pires, M. M., Pinheiro, C., Cordeiro, M., Bebiano, G., Costa, P., Palmeirim, I., Reis, R. M., \& Baltazar, F. (2013).

Monocarboxylate transporters (MCTs) in gliomas: Expression and exploitation as therapeutic targets. Neuro-Oncology, 15, 172-188.

Moreira, L., Dias, L. G., Pereira, J. A., \& Estevinho, L. (2008). Antioxidant properties, total phenols and pollen analysis of propolis samples from Portugal. Food and Chemical Toxicology: An International Journal Published for the British Industrial Biological Research Association, 46, 3482-3485.

Newman, D. J., \& Cragg, G. M. (2007). Natural products as sources of new drugs over the last 25 years. Journal of Natural Products, 70, 461-477.

Ordonez, R. M., Zampini, I. C., Moreno, M. I., \& Isla, M. I. (2011). Potential application of Northern Argentine propolis to control some phytopathogenic bacteria. Microbiological Research, 166, 578-584.

Orsolic, N., \& Basic, I. (2003). Immunomodulation by watersoluble derivative of propolis: A factor of antitumor reactivity. Journal of Ethnopharmacology, 84, 265-273.

Park, S. I., Ohta, T., Kumazawa, S., Jun, M., \& Ahn, M. R. (2014). Korean propolis suppresses angiogenesis through inhibition of tube formation and endothelial cell proliferation. Natural Product Communications, 9, 555-560.

Pellati, F., Orlandini, G., Pinetti, D., \& Benvenuti, S. (2011). HPLCDAD and HPLC-ESI-MS/MS methods for metabolite profiling of propolis extracts. Journal of Pharmaceutical and Biomedical Analysis, 55, 934-948.

Popova, M., Bankova, V., Butovska, D., Petkov, V., NikolovaDamyanova, B., Sabatini, A. G., Marcazzan, G. L., \& Bogdanov, S. (2004). Validated methods for the quantification of biologically active constituents of poplar-type propolis. Phytochemical Analysis, 15, 235-240.

Pratsinis, H., Kletsas, D., Melliou, E., \& Chinou, I. (2010). Antiproliferative activity of Greek propolis. Journal of Medicinal Food, 13, 286-290.

Scazzocchio, F., D’Auria, F. D., Alessandrini, D., \& Pantanella, F. (2006). Multifactorial aspects of antimicrobial activity of propolis. Microbiological Research, 161, 327-333.

Sforcin, J. M., \& Bankova, V. (2011). Propolis: Is there a potential for the development of new drugs? Journal of Ethnopharmacology, 133, 253-260.

Silva, J. C., Rodrigues, S., Feas, X., \& Estevinho, L. M. (2012). Antimicrobial activity, phenolic profile and role in the inflammation of propolis. Food and Chemical Toxicology: An International Journal Published for the British Industrial Biological Research Association, 50, 1790-1795. 
Singleton, V. L., Orthofer, R., \& Lamuela-Raventos, R. M. (1999). Analysis of total phenols and other oxidation substrates and antioxidants by means of Folin-Ciocalteu reagent. Methods in Enzymology, 299, 152-178.

Sulaiman, G. M., Ad'hiah, A. H., Al-Sammarrae, K. W., Bagnati, R., Frapolli, R., Bello, E., Uboldi, S., Romano, M., Panini, N., Scanziani, E., Pezzolato, M., Erba, E., \& D'Incalci, M. (2012). Assessing the anti-tumour properties of Iraqi propolis in vitro and in vivo. Food and Chemical Toxicology: An International Journal Published for the British Industrial Biological Research Association, 50, 1632-1641.

Szliszka, E., Czuba, Z. P., Bronikowska, J., Mertas, A., Paradysz, A., \& Krol, W. (2011a). Ethanolic extract of propolis augments TRAIL-induced apoptotic death in prostate cancer cells. Evidence-based Complementary and Alternative Medicine, 2011, 535172.

Szliszka, E., Zydowicz, G., Janoszka, B., Dobosz, C., KowalczykZiomek, G., \& Krol, W. (2011b). Ethanolic extract of Brazilian green propolis sensitizes prostate cancer cells to TRAILinduced apoptosis. International Journal of Oncology, 38, 941953.

Szliszka, E., Zydowicz, G., Mizgala, E., \& Krol, W. (2012). Artepillin C (3,5-diprenyl-4-hydroxycinnamic acid) sensitizes LNCaP prostate cancer cells to TRAIL-induced apoptosis. International Journal of Oncology, 41, 818-828.

Tolba, M. F., Esmat, A., Al-Abd, A. M., Azab, S. S., Khalifa, A. E., Mosli, H. A., Abdel-Rahman, S. Z., \& Abdel-Naim, A. B. (2013). Caffeic acid phenethyl ester synergistically enhances docetaxel and paclitaxel cytotoxicity in prostate cancer cells. IUBMB Life, 65, 716-729.

Ueda, M., Hayashibara, K., \& Ashida, H. (2013). Propolis extract promotes translocation of glucose transporter 4 and glucose uptake through both PI3K- and AMPK-dependent pathways in skeletal muscle. Biofactors (Oxford, England), 39, 457466.
Umthong, S., Phuwapraisirisan, P., Puthong, S., \& Chanchao, C. (2011). In vitro antiproliferative activity of partially purified Trigona laeviceps propolis from Thailand on human cancer cell lines. BMC Complementary and Alternative Medicine, 11, 37.

Valença, I., Morais-Santos, F., Miranda-Goncalves, V., Ferreira, A. M., Almeida-Aguiar, C., \& Baltazar, F. (2013). Portuguese propolis disturbs glycolytic metabolism of human colorectal cancer in vitro. BMC Complementary and Alternative Medicine, 13, 184.

Valente, M. J., Baltazar, A. F., Henrique, R., Estevinho, L., \& Carvalho, M. (2011). Biological activities of Portuguese propolis: Protection against free radical-induced erythrocyte damage and inhibition of human renal cancer cell growth in vitro. Food and Chemical Toxicology: An International Journal Published for the British Industrial Biological Research Association, 49, 86-92.

Viuda-Martos, M., Ruiz-Navajas, Y., Fernandez-Lopez, J., \& PerezAlvarez, J. A. (2008). Functional properties of honey, propolis, and royal jelly. Journal of Food Science, 73, R117-R124.

Watanabe, M. A., Amarante, M. K., Conti, B. J., \& Sforcin, J. M. (2011). Cytotoxic constituents of propolis inducing anticancer effects: A review. The Journal of Pharmacy and Pharmacology, 63, 1378-1386.

Woisky, R. G., \& Salatino, A. (1998). Analysis of propolis: Some parameters and procedures for chemical quality control. Journal of Apicultural Research, 37, 99-105.

Wu, J., Omene, C., Karkoszka, J., Bosland, M., Eckard, J., Klein, C. B., \& Frenkel, K. (2011). Caffeic acid phenethyl ester (CAPE), derived from a honeybee product propolis, exhibits a diversity of anti-tumor effects in pre-clinical models of human breast cancer. Cancer Letters, 308, 43-53.

Xuan, H., Li, Z., Yan, H., Sang, Q., Wang, K., He, Q., Wang, Y., \& Hu, F. (2014). Antitumor activity of Chinese propolis in human breast cancer MCF-7 and MDA-MB-231 cells. Evidence-based Complementary and Alternative Medicine, 2014, 280120. 